\title{
Don't know what to call him but he's mighty lak a rose - Rebecca Wolff
}

It is a red wax candle

between us on the table. Lurid,

in decay. Do you want to make something

of it? It is melting,

slipping out pools of its own soft

heart: blood running under a door.

Somebody smells like honeysuckle he says.

We have just enough wine tonight.

There are several liquids at this table;

his dewy eyes, clear white, bright blue.

It is round and sacrilegious,

squat, advantageous. And my friend is orgasmic,

always a distinction to be made. I never saw the like

before tonight, when I looked down from our chatter

and he stopped before I came. Don't give up on glamour,

it is apportioned: I am rolling a rose (in bloom) lipstick-true

out of the run-off. I hand it over to you

you are flirting your face off.

It is all so base, no matter how we

elevate it to the level of this object;

this subject. If you are not your body and you are not your mind ...

your beard knits your head and chest together. Others subject themselves at the outset, prostrated, and that is a prerequisite.

Just don't hurt me. 